\title{
Tables, Figures, and Maps
}

Tables

I. Communities Which Retained Communal Land in the Districts of Alarcón and Hidalgo by $1910 \quad 46$

2. Owners of More Than 2,000 Hectares in the Districts of Alarcón and Hidalgo (circa 1910) 65

3. Rents Paid for Land in the Districts of Alarcón and Hidalgo 70

4. Percentage of Heads of Family and Adult Males Who Owned Land in Fifty-three Towns and Villages of the Districts of Alarcón and Hidalgo (1919-1940)

$14 I$

s. Percentage of Heads of Family and Adult Males Owning Twenty Hectares or More in Six Towns and Villages of the Districts of Alarcón and Hidalgo (1919-1940) I4I

6. Percentage of Adult Males and Heads of Household Owning Livestock in Forty-five Towns and Villages in the Districts of Alarcón and Hidalgo (1919-1940) 142

7. Percentage of Adult Males and Heads of Household Owning Livestock in Forty-two Towns and Villages in the Districts of Alarcón and Hidalgo (1919-1940) by Types 142

8. Requests for Ejidos in the Districts of Alarcón and Hidalgo (1919-1940) 146

9. Landowners Affected by the Agrarian Reform in the Districts of Alarcón and Hidalgo (1919-1940) Iso

10. Numbers of Eligible Individuals Granted and Refused Land in the Districts of Alarcón and Hidalgo (1919-1940) I 33

II. Type of Land Granted in Presidential Resolutions in the Districts of Alarcón and Hidalgo (1919-1940) IS 3

Figures

I. Population Density, 1910: Districts of Alarcón and Hidalgo Compared to Average for Guerrero 
viii Tables, Figures, and Maps

2. Economically Active Population by Sector, 1910 34

3. Population of the Districts of Alarcón and Hidalgo, I9IO, I92 I, I940 $\quad$ I39

4. Economically Active Population by Sector, $1940 \quad 140$

5. Area of Land Granted in Guerrero, I919-1940 148

6. Area of Land Granted in the District of Alarcón, 1919-1940 148

7. Area of Land Granted in the District of Hidalgo, 1919-1940 I49

Maps

I. Guerrero

2. Districts of Alarcón and Hidalgo 32 